\title{
Role of Adhesive Proteins in Platelet Tumor Interaction In Vitro and Metastasis Formation In Vivo
}

\author{
S. Karpatkin, ${ }^{*}$ E. Pearlstein, ${ }^{\star *}$ C. Ambrogio, ${ }^{\star \star}$ and B. S. Coller \\ ${ }^{*}$ Departments of Medicine and ${ }^{\ddagger}$ Pathology and ${ }^{* \ddagger}$ Kaplan Cancer Center, New York University Medical Center, New York, New York \\ 10016; and Division of Hematology, Department of Medicine, State University of New York at Stony Brook, Stony Brook, New York 11794
}

\begin{abstract}
Platelet-adhesive protein-tumor cell interaction was studied in vitro and in vivo. Monoclonal antibody 10E5, which inhibits binding of fibronectin and von Willebrand factor to the platelet membrane glycoprotein GPIIb-GPIIIa complex, inhibited the binding of mouse CT26 and human HCT8 colon carcinoma cells to platelets by $63-65 \%$, whereas an irrelevant monoclonal antibody, 3B2, had no effect. Monoclonal antibody 6D1, which inhibits binding of von Willebrand factor to GPIb, also had no effect. RGDS, a tetrapeptide that represents the adhesive domain of fibronectin and von Willebrand factor inhibited binding of the tumors to platelets by $64-69 \%$. Monospecific polyclonal antifibronectin antibody inhibited binding by $60-82 \%$; anti-von Willebrand factor antibody inhibited binding by 75-81\%.

In vivo, polyclonal monospecific anti-mouse von Willebrand factor antibody inhibited pulmonary metastases induced by CT26 tumor cells by 53-64\%, B16a amelanotic melanoma cells by $45 \%$ and T241 Lewis bladder cells by $46 \%$ without induction of thrombocytopenia. Pulmonary metastases with CT26 cells could be inhibited by induction of thrombocytopenia, and reconstituted by infusion of either murine or human platelets. Reconstitution of pulmonary metastases with human platelets could be inhibited $77 \%$ by preincubation of human platelets with monoclonal antibody $10 E 5$ before infusion of platelets into mice.

Thus, platelets appear to contribute to metastases by their adhesive interaction with tumor cells via the adhesive proteins fibronectin and von Willebrand factor.
\end{abstract}

\section{Introduction}

The requirement of platelets for murine pulmonary metastasis has been recognized for more than 18 years $(1,2)$. However, the mechanism of this requirement is poorly understood. For example, there is considerable controversy regarding the efficacy of antiplatelet agents in the prevention of metastases. Gasic et al. (3) reported that aspirin decreased metastases in

Presented at the 28th Annual Meeting of the American Society of Hematology, San Francisco, CA, 8 December 1986, and published in abstract form (1986. Blood. 68(Suppl.):319A).

Address reprint requests to Dr. Karpatkin, Department of Medicine, New York University Medical School, 550 First Avenue, New York, NY 10016.

Received for publication 18 January 1987 and in revised form 2 November 1987.

J. Clin. Invest.

(c) The American Society for Clinical Investigation, Inc.

0021-9738/88/04/1012/08 $\$ 2.00$

Volume 81, April 1988, 1012-1019 mice given injections of MCA2 and Y241 fibrosarcoma cells. Kolenich et al. (4) made similar observations with BW10232 adenocarcinoma of rabbits. However, Wood and Hilgard (5) obtained negative results with a V2 carcinoma of rabbits as did Hilgard et al. (6) in a careful study of Lewis lung carcinoma in mice; the latter group also found two other antiplatelet agents, bencyclane and RA 233 (a dipyridamole derivative), to be without effect. Gordon et al. (7), using pentoxifyllin (a phosphodiesterase inhibitor) as an antiplatelet agent, obtained positive results with a Wilms' tumor of Wistar-Furth rats, equivocal results with a C1300 neuroblastoma of mice, and negative results with a National Institutes of Health renal adenocarcinoma of mice. More recently, Honn et al. (8) reported dramatic reduction of $\mathrm{B} 16$ amelanotic melanoma metastases in mice with the use of a combination of prostacyclin $\left(\mathrm{PGI}_{2}\right)$ and theophylline. We, however, could not demonstrate an antimetastatic effect of this drug combination (9) with B16 amelanotic melanoma, CT26 colon adenocarcinoma or Lewis lung carcinoma. In addition, we found that these tumor lines lose considerable metastatic potential, when maintained in vitro for a short period of time. Thus it is crucial that control and treated animals are injected according to an alternating regimen rather than injecting one group and then the other (9).

These disappointing observations prompted us to reconsider the role of platelets in tumor metastases. We were able to confirm the original results of Gasic et al. (1) in that antibodyinduced thrombocytopenia markedly reduced the number and volume of metastases produced by CT 26 colon adenocarcinoma, Lewis lung carcinoma and B16 amelanotic melanoma (2). A second attempt was therefore made to find antiplatelet agents capable of inhibiting metastases in the absence of thrombocytopenia. The rationale was to employ aspirin (at low and high dosage, since earlier experiments were performed before the knowledge of the inhibiting effect of aspirin on endothelial cell $\mathrm{PGI}_{2}$ production [10]), a drug that inhibits the secondary wave of platelet aggregation, and ticlopidine, a drug that inhibits the primary wave of platelet aggregation. These experiments again gave negative results and are reported here. This called for a different approach in delineating the mechanism of platelet requirement for tumor metastasis.

Attention was therefore directed toward platelet adhesion and platelet adhesive proteins, since antiplatelet agents used by previous investigators as well as ourselves, have little or no effect on platelet adhesion. The present communication details: (a) our successful in vivo results in inhibiting murine metastases of CT26 colon carcinoma cells with a polyclonal antibody directed against mouse von Willebrand factor, and a monoclonal antibody (10E5) directed against the common platelet adhesive protein receptor for fibronectin, von Willebrand factor and fibrinogen $(11,12) ;(b)$ our in vitro studies on inhibition of tumor-platelet adhesion with monoclonal 10E5, polyclonal antifibronectin antibody, RGDS (a tetrapeptide 
that inhibits the binding of all three adhesive proteins to platelets) (13), and polyclonal anti-von Willebrand factor antibody against murine and human von Willebrand factor, respectively.

\section{Methods}

Tumor cell lines and tissue culture media. CT26, $N$-nitroso- $N$-methylurethane-induced mouse undifferentiated colon carcinoma cells (14) were obtained through the courtesy of Dr. M. H. Goldrosen of Roswell Park Memorial Institute, Buffalo, NY, and grown in RPMI 1640 containing 10\% fetal bovine serum (Gibco, Grand Island, NY). Lewis lung carcinoma cells were obtained from Mason Laboratories, Worcester, MA and grown in the same medium as CT 26 cells. HCT 8 spontaneous human colon adenocarcinoma cells were obtained through the courtesy of Dr. E. Cadman, Cancer Institute, University of California, San Francisco, and grown in the same medium as CT26 cells. B16 amelanotic melanoma cells (B16a) were obtained through the courtesy of Dr. C. Maniglia, Yale University Medical School and grown in Dulbecco's minimal essential medium-glucose $(0.45 \mathrm{~g} / 100 \mathrm{ml})$ plus $10 \%$ fetal bovine serum. Lewis bladder T241 cells were obtained through the courtesy of Dr. G. Mayo, D.C.T. Tumor Repository, Frederick, $\mathrm{MD}$, and grown in the same medium as the CT26 and Lewis lung cell lines. Lewis lung and B16a cells were maintained by serial passage with subcutaneous injections in syngeneic mice. In preparation for in vivo experiments, they were grown for 5-7 d in tissue culture medium and harvested at or near confluence as described previously (9). CT26 cells were maintained in tissue culture and replenished from frozen stocks.

Platelet aggregation. Platelet-rich plasma was prepared from heparinized rabbit or murine blood and tested as described previously (9) using an aggregometor (Bio-Data Corp., Willow Grove, PA).

Antiplatelet agent (aspirin, ticlopidine) in vivo protocol. BALB/c female mice (Taconic Laboratories, Germantown, NY) or C57B1/6 female mice (Jackson Laboratories, Bar Harbor, ME) were pretreated with intraperitoneal aspirin or vehicle for $2 \mathrm{~d}$ before the intravenous injection of 50,000 CT26 colon adenocarcinoma cells (BALB/c) or 150,000 Lewis lung cells (C57B1/6). Additional injections were given the day of inoculation, daily for $1 \mathrm{wk}$, and every other day thereafter until sacrifice on day 21 . Similar mice were treated orally with ticlopidine or water (with the aid of a special blunted needle from Thomas Scientific, Philadelphia, PA) for $2 \mathrm{~d}$ before the intravenous injection of tumor cells, on the day of injection, and $1 \mathrm{~d}$ later. Animals were sacrificed on day 21. Animals from each experimental group were alternated for each tumor cell injection to adjust for any lability of metastatic potential by tumor cells stored in vitro before injection (9). Pulmonary metastases were scored for number and volume as described previously (9).

Anti-von Willebrand factor antibody in vivo protocol. Mice were injected intraperitoneally with $100 \mu$ l of rabbit antimouse von Willebrand factor antisera or nonimmune sera $6 \mathrm{~h}$ and $1 \mathrm{~h}$ before tumor cell injection, and $6 \mathrm{~h}$ postinjection of tumor cells (25-50,000 CT26 cells, 25,000 B16a cells, 200,000 T241 Lewis bladder cells). Animals were sacrificed on day 21 .

Antiplatelet adhesive protein receptor monoclonal antibodies and in vivo protocol. The production, characterization, purification and fragmentation of antibodies $10 \mathrm{E} 5$ and $6 \mathrm{D} 1$ into $\mathrm{F}\left(\mathrm{ab}^{\prime}\right)_{2}$ fragments has been described in detail previously $(15,16)$. Antibody $3 B 2$, prepared, purified and fragmented as described previously (17), served as a control; it binds to glycoprotein (GP)IIb ${ }^{1}$ and the GPIIb-GPIIIa complex, but does not inhibit platelet function. Antibody 10E5 binds to the platelet glycoprotein GPIIb/GPIIIa complex and prevents the binding of $\mathrm{f}$ brinogen, fibronectin, and von Willebrand factor to the adhesive protein receptor when platelets are activated by a variety of agonists.

1. Abbreviations used in this paper: ASA, acetylsalicylic acid; GP, glycoprotein.
Because this antibody does not bind to mouse platelets, it was necessary to develop an in vivo platelet reconstitution system wherein mice were depleted of platelets with antiplatelet antibody and then transfused with human platelets that were either incubated with $F\left(a b^{\prime}\right)_{2}$ fragments of monoclonal antibodies or incubated untreated. Since murine metastasis could be reconstituted in thrombocytopenic mice with human platelets, such an experiment became feasible. One group of mice was injected with $100 \mu \mathrm{l}$ i.p. of rabbit nonimmune sera $6 \mathrm{~h}$ before the intravenous injection of 50,000 CT26 tumor cells and injected with $200 \mu$ li.v. of vehicle $30 \mathrm{~min}$ before the injection of tumor cells. A second group was injected with rabbit antimouse platelet sera (to lower the platelet count to 7-10\% of normal levels), and injected with vehicle and tumor cells as above. A third group was injected with the anti-mouse platelet sera as above and then injected with $5 \times 10^{8}$ human platelets in $200 \mu$ l of vehicle (purified by Stractan gradient, see below) 30 min before the injection of tumor cells. A fourth group was treated exactly as the third except that the human platelets were incubated with $25 \mu \mathrm{g}$ of the $\mathrm{F}\left(\mathrm{ab}^{\prime}\right)_{2}$ fragments of monoclonal antibody for $30 \mathrm{~min}$ at room temperature, before the injection of tumor cells. Animals from each experimental group were alternated.

Animals were sacrificed at $21 \mathrm{~d}$ by cervical dislocation, and the pulmonary parenchyma removed and fixed in Perfix (Fisher Scientific Co., Springfield, NJ) for $2 \mathrm{~h}$. Visible metastases were restricted to the lungs. The number and size of nodules were classified into three categories: $<0.5 \mathrm{mM}, 0.6$ to $2 \mathrm{mM}$ and $>2 \mathrm{mM}$ in diameter. The volume of each nodule was calculated from its diameter, assuming a sphere. The mean number of metastases represents the sum of the number of pulmonary metastases for each mouse divided by the number of mice in the group. The average nodule volume for each mouse represents the pulmonary tumor volume divided by the number of nodules for each mouse. The mean nodule volume for the group represents the sum of the average nodule volumes divided by the number of mice in the group. The tumor pulmonary volume for each mouse was calculated by multiplying its mean nodule volume by its number of metastases. The total mean lung volume represents the sum of the total tumor pulmonary volumes for each mouse divided by the number of mice in each group.

Anti-von Willebrand factor antibody. Mouse von Willebrand factor was prepared from $200 \mathrm{ml}$ of mouse blood collected into a diluent containing (final concentration) $10 \mathrm{mM}$ EDTA, $10 \mathrm{U} / \mathrm{ml}$ heparin, 10 $\mathrm{U} / \mathrm{ml}$ aprotinin, $2 \mathrm{mM}$ phenylmethylsulfonyl fluoride. The plasma was separated by centrifugation and frozen at $-70^{\circ} \mathrm{C}$. The frozen material was thawed at $0^{\circ} \mathrm{C}$ and the resulting cryoprecipitate collected by centrifugation and dissolved in $0.05 \mathrm{M}$ Tris buffer, $\mathrm{pH} 7.4$ containing $0.154 \mathrm{M} \mathrm{NaCl}, 0.1 \% \mathrm{NaN}_{3}$. The soluble material was then filtered on a Sepharose 4B column that had been equilibrated in the same buffer except for sodium azide concentration, which was changed to $0.02 \%$. The void volume fraction had a peak in an almost identical region as human von Willebrand factor, similarly prepared. The human von Willebrand factor was devoid of fibrinogen as determined with a rabbit anti-human fibrinogen antibody by Laurell rocket immunoelectrophoresis (18). The mouse von Willebrand factor was unreactive with the same antibody.

Rabbit antimouse von Willebrand factor was raised in a rabbit and absorbed with monolayers of CT26 cells. This antibody inhibited ristocetin-induced aggregation of human platelet-rich plasma. Mouse platelets do not aggregate with ristocetin (19). The rabbit antimouse von Willebrand factor antibody had trace cross-reactivity with fibronectin (concentrated antibody, $370 \mu \mathrm{g} / \mathrm{ml}$, had 1/500 the activity of a potent antifibronectin antibody using an ELISA assay). In some vitro experiments, this antibody was further absorbed with fibronectin bound to gelatin coupled to Sepharose $4 \mathrm{~B}$ with cyanogen bromide (20), with identical results obtained. The antimouse von Willebrand factor antibody did not cross-react with fibrinogen.

Rabbit-anti-mouse anti-platelet antibody. The production of this antibody and its absorption with mouse red blood cells and tumor cells has been described (2). The antibody was specific for platelets. The platelet suspension used to raise the antibody had an occasional red 
Table I. Effect of Low and High Dose Aspirin on Development of Pulmonary Metastases after Intravenous Injection of CT26 Colon or Lewis Lung Carcinoma Cells

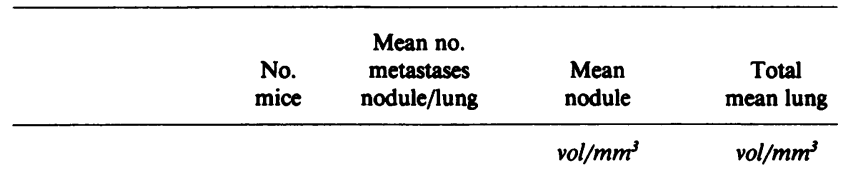

\section{CT26 cells}

$\begin{array}{lllll}\text { Control } & 29 & 52.3 \pm 6.8 & 1.19 \pm 0.04 & 54.5 \pm 11.4 \\ 0.1-0.5 \mathrm{mg} / \mathrm{kg} & 62 & 55.5 \pm 7.9 & 1.08 \pm 0.06 & 53.7 \pm 12.8 \\ 2.5 \mathrm{mg} / \mathrm{kg} & 29 & 63.8 \pm 13.0 & 1.19 \pm 0.05 & 70.8 \pm 16.5 \\ \text { Lewis lung cells } & & & & \\ \text { Control } & 24 & 27.9 \pm 3.9 & 2.85 \pm 0.31 & 76.8 \pm 9.2 \\ 0.1-0.5 \mathrm{mg} / \mathrm{kg} & 37 & 25.0 \pm 2.8 & 2.86 \pm 0.47 & 66.4 \pm 11.3 \\ 2.5-25.0 \mathrm{mg} / \mathrm{kg} & 36 & 26.3 \pm 2.2 & 2.56 \pm 0.27 & 66.1 \pm 8.4\end{array}$

$\mathrm{Balb} / \mathrm{c}$ or $\mathrm{C} 57 \mathrm{Bl} / 6$ female mice were pretreated with aspirin or vehicle for $2 \mathrm{~d}$ before the intravenous injection of 50,000 CT26 colon adenocarcinoma cells or 150,000 Lewis lung cells. Additional aspirin was given the day of inoculation, daily for $1 \mathrm{wk}$ and then every other day until sacrifice on day 21 . Data are expressed as mean \pm SEM. Total mean lung tumor lung volume was calculated from the total tumor lung volume of each animal.

blood cell with no visible neutrophils or mononuclear cells seen under phase microscopy. When $100 \mu \mathrm{l}$ was given intraperitoneally, it decreased the mouse $(\mathrm{Balb} / \mathrm{c})$ platelet count from $1.46 \pm 0.08 \times 10^{6}$ platelets $/ \mu \mathrm{l}$ to $0.12 \pm 0.03 \times 10^{6}$ platelets $/ \mu \mathrm{l}(8.0 \%$ baseline $)$ at $6 \mathrm{~h}, 7.7 \%$ at 24 $h, 6.0 \%$ at $48 \mathrm{~h}$, and $78.0 \%$ at $72 \mathrm{~h}(9)$. No effect was observed on mouse hematocrit, white blood cell count, or differential. Previous studies have revealed that the antimetastatic effect is eliminated if antiplatelet antibody is given $6 \mathrm{~h}$ after injection of tumor cells (9). Since antiplatelet antibody has its maximum effect at $6 \mathrm{~h}$, platelets are therefore required during the first $12 \mathrm{~h}$ of tumor inoculation.

In vitro platelet-tumor adhesion assay. Human platelets were separated from citrated platelet-rich plasma $(0.38 \%$ final concentration) on a Stractan gradient (see below) and suspended in $0.4 \%$ citrate-buffered saline-5 mM glucose, pH 7.4 at $10^{9}$ platelets $/ \mathrm{ml} .100 \mu \mathrm{l}$ were applied to flat-bottomed plastic microtiter wells (3072; Falcon Labware Fisher Scientific) and allowed to adhere for $24 \mathrm{~h}$ at $4^{\circ} \mathrm{C}$. Nonadherent platelets were removed by washing in $0.01 \mathrm{M} \mathrm{PBS}, \mathrm{pH} 7.4$ plus $1 \%$ BSA. 100 $\mu \mathrm{l}$ of this solution was then added to each well and incubated for $1 \mathrm{~h}$ at $37^{\circ} \mathrm{C}$ to block "free adherent" sites on the plastic. The microtiter wells were washed six times in PBS-BSA and then incubated for $1 \mathrm{~h}$ at $37^{\circ} \mathrm{C}$ in PBS-BSA with $\mathrm{F}\left(\mathrm{ab}^{\prime}\right)_{2}$ fragments of control or specific monoclonal or polyclonal antibodies. Microtiter plates were then washed three times as above and incubated with $10^{5}$ tumor cells suspended in $100 \mu \mathrm{l}$ of PBS containing $0.9 \mathrm{mM} \mathrm{CaCl}_{2}$ for $1 \mathrm{~h}$ at $37^{\circ} \mathrm{C}$. After washing three times, the adherent tumor cells were removed by trypsin-EDTA treatment (Gibco) and enumerated in a hemocytometer under phase microscopy.

Antifibronectin antibody. Fibronectin was purified from $250 \mathrm{ml}$ of citrated-human plasma containing $0.5 \mathrm{M}$ urea (21). The plasma was applied to a Sepharose 4B column equilibrated with $0.1 \mathrm{M}$ Tris buffer, pH 7.2 containing $1 \mathrm{mM}$ PMSF. The effluent was then applied to a gelatin Sepharose 4B affinity column prepared by coupling porcine skin gelatin, $3 \mathrm{mg} / \mathrm{ml}$ to cyanogen bromide activated 4B Sepharose (20). The column was washed with $0.05 \mathrm{M}$ Tris, $1 \mathrm{M}$ urea, $0.1 \mathrm{mM}$ PMSF, pH 7.5, and eluted with the same solution containing $4 \mathrm{M}$ urea. Peak tubes were pooled and dialyzed against water or appropriate buffer before lyophilization.

New Zealand White rabbits were immunized with $1 \mathrm{mg} / \mathrm{ml}$ of fibronectin per injection in $1 \mathrm{ml}$ of Freund's complete adjuvant (vol/ vol). They were injected initially in the foot pad and then weekly for 4 wk at six sites along the back. Serum was collected $5 \mathrm{~d}$ after the final injection and the IgG fraction purified by DEAE chromatography.

Preparation of platelets by Stractan gradient. Platelet-rich plasma ( $0.38 \%$ citrate) was placed on a discontinuous gradient of 10 and $20 \%$ Stractan (arabino-galactan polymer) dissolved in $13.6 \mathrm{mM}$ sodium citrate, $117 \mathrm{mM} \mathrm{NaCl}, 11 \mathrm{mM}$ glucose, $10 \mathrm{mM}$ sodium phosphate buffer, pH 7.4, $290 \mathrm{mosmol} /$ liter and centrifuged at $900 \mathrm{~g}$ for $25 \mathrm{~min}$. The interface contained platelets free of plasma. The platelets were suspended in the same buffer, enumerated by phase microscopy and diluted appropriately in this vehicle for in vivo and in vitro studies.

$R G D S$. The synthetic tetrapeptide, RGDS, was kindly synthesized for us by Dr. David Schlesinger of New York University Medical Center. It was purified by gel filtration on a G25 Sephadex column. Amino acid analysis revealed a ratio of amino acids of $1: 1: 1: 1$.

\section{Results}

Effect of low and high dose acetyl salicylic acid (ASA) on pulmonary metastases after intravenous injection of CT26 or Lewis lung carcinoma cells. ASA had no effect on the development of pulmonary metastases of CT26 or Lewis lung carcinoma cells injected into syngeneic mice at either the low $(0.1-0.5 \mathrm{mg} / \mathrm{kg})$ or high $(2.5-25.0 \mathrm{mg} / \mathrm{kg})$ dose (Table I). These concentrations of ASA were shown to inhibit murine platelet aggregation ex vivo with ADP or collagen.

Ticlopidine had no inhibitory effect on the development of pulmonary metastases of CT26 or Lewis lung carcinoma cells injected into syngeneic mice. On the contrary, ticlopidine enhanced the number of pulmonary metastases for both tumors, and increased the total tumor mass for CT26 cells, $P<0.001$ (Table II).

Table II. Effect of Ticlopidine on Development of Pulmonary Metastases after Intravenous Injection of Lewis Lung Cells or CT26 Cells

\begin{tabular}{|c|c|c|c|c|c|c|c|}
\hline & & & & $\mathrm{vol} / \mathrm{mm}^{3}$ & & $\mathrm{vol} / \mathrm{mm}^{3}$ & \\
\hline Control & 10 & $33.6 \pm 4.7$ & & $3.23 \pm 0.48$ & & $105.1 \pm 14.0$ & \\
\hline Ticlopidine $100 \mathrm{mg} / \mathrm{kg}$ po & 8 & $64.1 \pm 16.5$ & +91 & $2.12 \pm 0.56$ & -34 & $97.4 \pm 22.4$ & -7 \\
\hline \multicolumn{8}{|l|}{ CT26 Cells } \\
\hline Ticlopidine $100 \mathrm{mg} / \mathrm{kg}$ po & 32 & $32.8 \pm 4.5$ & +326 & $1.16 \pm 0.12$ & +49 & $45.6 \pm 6.7$ & +660 \\
\hline
\end{tabular}

Mice were pretreated with ticlopidine, $100 \mathrm{mg} / \mathrm{kg}$ for $2 \mathrm{~d}$ before the intravenous injection of either 150,000 Lewis lung cells or $50,000 \mathrm{CT} 26$ colon carcinoma cells. Additional ticlopidine was given during the day of injection and $1 \mathrm{~d}$ postinjection. Animals were sacrificed on day 21 . 
Effect of anti-mouse von Willebrand factor antibody on development of pulmonary metastases after intravenous injection of CT26, B16 amelanotic melanoma, or T241 Lewis bladder cells. Anti-mouse von Willebrand factor antibody inhibited pulmonary tumor metastases produced by all three tumors without lowering the animals' platelet count: $53-64 \%$ reduction of tumor mass for CT26 cells; $45 \%$ reduction for B16a cells; $46 \%$ reduction for T241 cells (Table III). No visible metastases were noted in any other organs. This suggested that an adhesive protein, von Willebrand factor, might contribute to the platelet requirement for tumor metastases. The inhibitory effect of the anti-mouse von Willebrand factor antibody was not due to cross-reactivity with tumor cells, since similar results were obtained after adsorption of the antibody with CT26 cells (experiments 3 and 4); nor was it due to cross-reactivity with fibronectin.

Effect of monoclonal antibody 10E5 on development of pulmonary metastases of CT26 cells after inhibition of metastases with anti-mouse platelet antibody and reconstitution with human platelets. Preliminary experiments showed that we could reverse the antimetastatic effect of the anti-platelet antibody with infusion of murine platelets (data not shown). This further substantiated the working of the antibody by decreasing the platelet count rather than by an effect on another cell type. Similar results were obtained with the transfusion of human platelets into mice after the injection of anti-mouse platelet antibody, but before the injection of either Lewis lung or CT26 tumor cells (Fig. 1). Full reconstitution of metastases was observed with the intravenous administration of enough human platelets to achieve a platelet count of 175,000 -
$200,000 / \mathrm{mm}^{3}$, which is approximately two- to threefold greater than the thrombocytopenic murine platelet count, but sixfold less than a normal murine platelet count. This reconstituted system was used to evaluate the in vivo effects of the monoclonal antibodies raised against human platelet membrane glycoproteins, since these antibodies do not cross-react with mouse platelets, and have no apparent cytotoxic effect on CT26 cells in vitro. When human platelets were preincubated with $\mathrm{F}\left(\mathrm{ab}^{\prime}\right)_{2}$ fragments of $10 \mathrm{E} 5$ before infusion into murine recipients, the human platelets failed to produce significant reconstitution of the metastases (Table IV). This effect of the 10E5 antibody was not due to the induction of thrombocytopenia because the platelet counts after infusion of human platelets were essentially the same, regardless of whether the platelets were pretreated with 10E5 or not. Marked inhibition of reconstitution was obtained in four of five different experiments and averaged $85 \%$ for 167 animals (range $66-100 \%$ ). In a fifth experiment employing 30 animals, reconstitution was inhibited by only $32 \%$. The average inhibition of reconstitution for all five experiments was $77 \%$. Control experiments employing the irrelevant monoclonal antibody 3B2, failed to inhibit reconstitution (two experiments, data not shown).

In vitro platelet-tumor adhesion. Experiments were next designed to study platelet-tumor adhesion in vitro. This was accomplished by measuring the ability of tumor cells to adhere to a platelet "lawn" laid down on microtiter plates. Platelets were pretreated with various monoclonal antibodies capable of binding to platelet membrane glycoproteins, monospecific rabbit polyclonal antibodies directed against human plasma fibronectin and von Willebrand factor, respectively, a mono-

Table III. Effect of Anti-von Willebrand Factor Antibody on the Development of Pulmonary Metastases after Intravenous Injection of Three Murine Tumors into Syngeneic Mice*

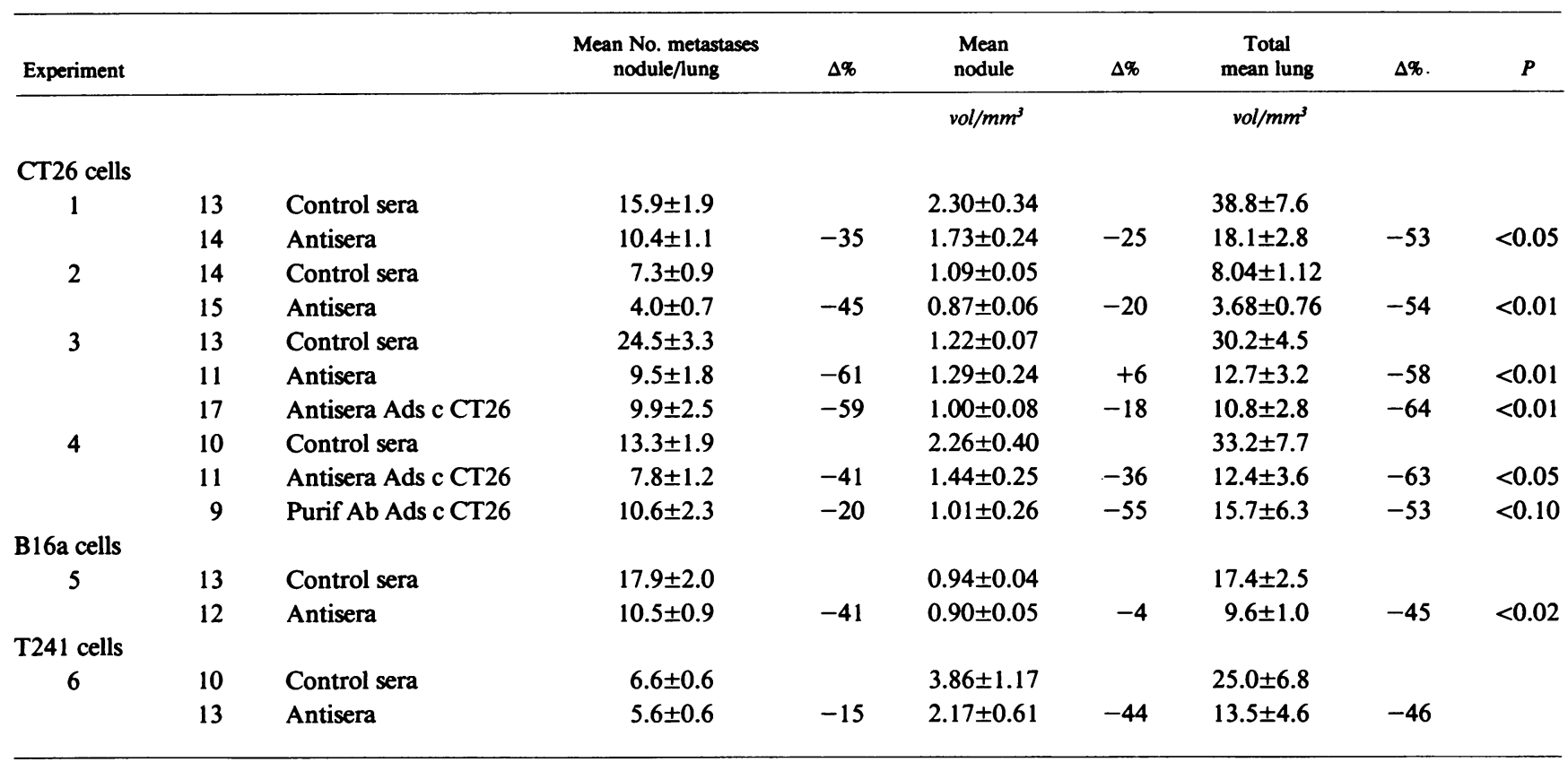

\footnotetext{
* $100 \mu \mathrm{l}$ rabbit antimouse von Willebrand factor sera or nonimmune control rabbit sera were given intraperitoneally $6 \mathrm{~h}$ preinjection, $1 \mathrm{~h}$ preinjection, and $6 \mathrm{~h}$ postinjection of tumor cells. Animals were sacrificed after 3 wk and pulmonary metastases were enumerated. 25,000 viable CT 26 cells were given intravenously to female Balb/c mice. 50,000 viable CT26 cells were given intravenously to female Balb/c mice. 25,000 viable B16a cells were given intravenously to female C57Bl/6 mice. 200,000 viable T241 cells were given intravenously to female C57B1/6 mice. Anti-vWF sera was adsorbed with CT26 monolayers. Anti-vWF serum partially purified with 50\% saturated ammonium sulfate and adsorbed with CT26 monolayers.
} 


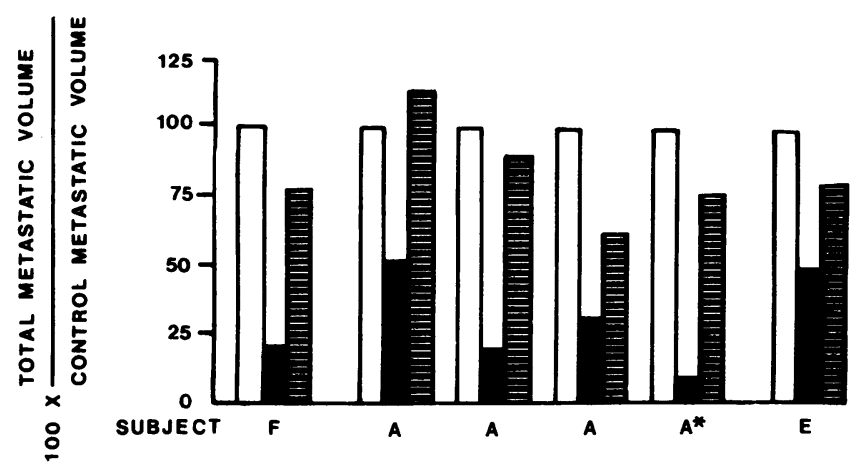

Figure 1. Reconstitution of pulmonary metastases in thrombocytopenic mice with infusion of human platelets. Mice were injected intraperitoneally with antiplatelet antibody or nonimmune rabbit serum $6 \mathrm{~h}$ before the intravenous injection of tumor cells. Human platelets or vehicle were given intravenously $45 \mathrm{~min}$ before tumor cells. First open bar refers to $100 \%$ control metastases; second solid bar refers to the effect of anti-platelet antibody on reduction of metastases as percent of the control metastases. Third hatched bar refers to reconstitution of metastases by human platelets as a percent of control. Letters refer to the subject whose platelets were tested; $A^{*}$, the dose and tumor used were 150,000 Lewis lung cells into C57B1/ 6 mice. All other experiments employed 50,000 CT26 cells into Balb/c mice.

specific rabbit polyclonal antibody directed against mouse von Willebrand factor, and a tetrapeptide, RGDS, which has been shown to inhibit the binding of von Willebrand factor, fibronectin, and fibrinogen to platelet GPIIb/GPIIIa.

$\mathrm{F}\left(\mathrm{ab}^{\prime}\right)_{2}$ fragments of monoclonal $10 \mathrm{E} 5$, anti-fibronectin antibody and RGDS consistently blocked the adhesion of CT26 tumor cells to human platelets by $63-82 \%$ (Table V). Similar results were obtained with a rabbit monospecific polyclonal antibody directed against mouse von Willebrand factor, employing mouse platelets (Table V). Similar results were ob- tained in additional experiments after adsorption of this antibody with fibronectin at three different concentrations of antibody. Thus with unadsorbed antibody inhibition at 37, 3.7, and $0.37 \mu \mathrm{g} / \mathrm{ml}$ of antibody was $-64 \pm 13$ (SEM), $-54 \pm 15$, and $-41 \pm 14 \%$, respectively, compared with inhibition with adsorbed antibody of $-60 \pm 17,-48 \pm 14$, and $-53 \pm 15 \%$, respectively (four experiments). In addition, a rabbit monospecific polyclonal antibody directed against human von Willebrand factor (which did not react with fibronectin) inhibited the binding of human HCT8 cells to human platelets. Negative results were obtained with $\mathrm{F}\left(\mathrm{ab}^{\prime}\right)_{2}$ fragments of monoclonal 6D1, which binds to glycoprotein (GP)Ib, and inhibits ristocetin-induced platelet aggregation, and 3B2, which binds to glycoprotein GPIIb and the GPIIb-IIIa complex, but does not inhibit platelet aggregation.

\section{Discussion}

These data indicate a role for platelet-tumor adhesion in the development of experimental pulmonary metastases in mice, mediated by the adhesive proteins fibronectin and von Willebrand factor. Previous work had been directed toward the role of pharmacologic agents that could inhibit tumor-induced platelet aggregation (3-9). However, the effect of anti-platelet aggregating agents has been controversial in other laboratories (3-8) and nonreproducible in our own (9). Our inability to inhibit pulmonary metastases with the antiplatelet aggregating agents aspirin, ticlopidine, and prostacyclin (9), as well as the lack of effect of these agents on platelet adhesion, prompted us to examine the role of adhesive proteins in the platelet requirement for tumor metastases.

The recent knowledge and availability of the specific adhesive protein inhibitor $\operatorname{RGDS}(13,22,23)$, a tetrapeptide that inhibits the binding of fibrinogen, fibronectin and von Willebrand factor to platelets (13), as well as the monoclonal antibody $10 \mathrm{E} 5$ (12), a specific inhibitor of the common adhesive protein receptor for these three adhesive proteins, on platelets,

Table IV. Effect of Monoclonal Antibody 10E5 on Reconstitution of Murine Metastases with Human Platelets after Inhibition of Metastases by Induction of Thrombocytopenia*

\begin{tabular}{|c|c|c|c|c|c|c|}
\hline \multirow[b]{2}{*}{ Experiment } & \multirow[b]{2}{*}{$n$} & \multirow[b]{2}{*}{ Control } & \multicolumn{4}{|c|}{ Mean total nodule $\left(\mathrm{vol} / \mathrm{mm}^{3}\right)$} \\
\hline & & & $\begin{array}{l}\text { Antiplatelet } \\
\text { antibody }\end{array}$ & $\begin{array}{c}\text { Antiplatelet } \\
\mathbf{A b}+\text { platelets }\end{array}$ & $\begin{array}{c}\text { Antiplatelet } \mathrm{Ab} \\
+ \text { platelets + 10E5 }\end{array}$ & $\begin{array}{l}\text { Inhibition of } \\
\text { reconstitution }\end{array}$ \\
\hline & & & & & & $\%$ \\
\hline 1 & 45 & $61.9 \pm 8.7$ & $37.1 \pm 8.7$ & $61.1 \pm 13.8$ & $36.8 \pm 6.4$ & 100 \\
\hline 2 & 50 & $10.4 \pm 1.7$ & $3.0 \pm 0.6$ & $10.6 \pm 2.8$ & $3.6 \pm 0.5$ & 92 \\
\hline 3 & 20 & $31.0 \pm 10.5$ & $7.4 \pm 3.0$ & $16.3 \pm 3.2$ & $10.4 \pm 2.9$ & 66 \\
\hline 4 & 30 & $16.6 \pm 4.5$ & $4.9 \pm 1.2$ & $14.1 \pm 4.7$ & $11.2 \pm 5.4$ & 32 \\
\hline 5 & 52 & $18.0 \pm 3.2$ & $6.3 \pm 1.3$ & $9.8 \pm 1.6$ & $7.2 \pm 1.4$ & 74 \\
\hline Mean & & $27.3 \pm 5.0$ & $12.4 \pm 3.0$ & $23.0 \pm 5.3$ & $14.0 \pm 3.1$ & 77 \\
\hline
\end{tabular}

\footnotetext{
* Control mice (column 3) received $100 \mu \mathrm{l}$ of nonimmune mouse serum $6 \mathrm{~h}$ prior to the intravenous injection of 50,000 CT26 tumor cells. Thrombocytopenic mice (column 4) received $100 \mu$ l of rabbit anti-mouse platelet serum $6 \mathrm{~h}$ before injection of CT 26 cells. The reconstituted group of mice (column 5 ) received $5 \times 10^{8}$ human platelets $5 \frac{1}{2} \mathrm{~h}$ after injection of antiplatelet antibody and 30 min before the injection of tumor cells. The mice reconstituted with 10E5-treated platelets (column 6 ) were identical to the third group except for preincubation of human platelets with $25 \mu \mathrm{g}$ of $\mathrm{F}\left(\mathrm{ab}^{\prime}\right)_{2}$ fragments of $10 \mathrm{E} 5$ for $30 \mathrm{~min}$ at room temperature before their injection. Mean refers to the "weighted" mean for the number of experiments. $n$, the total number of animals in each experiment. SEM is given. Percent inhibition of reconstitution refers to the difference between column 6 and column 5 divided by the difference between column 5 and column 4 .
} 
Table V. Effect of Antiplatelet Monoclonal Antibodies 10E5, 6D1, 3B2, Polyclonal Antifibronectin Antibody, Polyclonal Anti-von Willebrand Factor Antibody and Peptide RGDS on the Adhesion of CT26 and HCT8 Tumor Cells to Platelets In Vitro*

\begin{tabular}{|c|c|c|c|c|}
\hline$n$ & Treatment & $\begin{array}{l}\text { Tumor cells } \times 10^{-3} \\
\text { bound to platelets }\end{array}$ & $\Delta \%$ & $P$ \\
\hline \multicolumn{5}{|c|}{ CT26 Cells } \\
\hline 10 & RGDS & $4.0 \pm 0.7$ & -64 & $<0.001$ \\
\hline 8 & 10E5 & $4.0 \pm 1.4$ & -63 & $=0.04$ \\
\hline 6 & 6D1 & $9.8 \pm 3.9$ & -10 & $>0.1$ \\
\hline 8 & Antifibronectin antibody & $2.0 \pm 0.3$ & -82 & $<0.001$ \\
\hline 5 & Nonimmune IgG & $7.7 \pm 1.8$ & & \\
\hline 5 & Anti-mouse vWF antibody & $1.9 \pm 1.0$ & -75 & $=0.01$ \\
\hline \multicolumn{5}{|c|}{ HCT8 Cells } \\
\hline 6 & Buffer & $7.4 \pm 1.4$ & & \\
\hline 6 & RGDS & $2.3 \pm 0.6$ & -69 & $=0.01$ \\
\hline 6 & Anti-human vWF antibody & $1.4 \pm 0.4$ & -81 & $=0.005$ \\
\hline
\end{tabular}

* $1 \times 10^{8}$ Stractan-separated platelets were incubated with flat-bottomed plastic microtiter plates for $24 \mathrm{~h}$ at $4^{\circ} \mathrm{C}$, followed by addition of $0.01 \mathrm{M}$ PBS, pH $7.4+1 \% \mathrm{BSA}$ for $1 \mathrm{~h}$ at $37^{\circ} \mathrm{C}$ to block "free adherent" sites on the plastic. Buffer $+\mathrm{BSA}$ or $\mathrm{F}(\mathrm{ab} \text { ') })_{2}$ fragments of monoclonal antibody 10E5, 6D1, or $3 B 2(25 \mu \mathrm{g} / \mathrm{ml})$ or the peptides RGDS $(25 \mu \mathrm{g} / \mathrm{ml})$ or rabbit anti-human fibronectin IgG or rabbit anti-human von Willebrand factor IgG $(6 \mu \mathrm{g} / \mathrm{ml})$ or rabbit antimouse von Willebrand factor IgG (37 $\mu \mathrm{g} / \mathrm{ml})$ or nonimmune rabbit IgG $(6 \mathrm{or} 37 \mu \mathrm{g} / \mathrm{ml}$, respectively) were then added for $1 \mathrm{~h}$ at $37^{\circ} \mathrm{C}$, washed, followed by the addition of $1 \times 10^{5}$ mouse CT26 or human $\mathrm{HCT} 8$ cells for $1 \mathrm{~h}$ at $37^{\circ} \mathrm{C}$ in PBS- 0.9 $\mathrm{mM} \mathrm{CaCl}_{2}$. Nonadherent tumor cells were washed away, and the adherent tumor cells released into the supernatant with trypsin-EDTA.

Tumor cells were then counted directly in a counting chamber under phase microscopy. Background adhesion of tumor cells to microtiter wells $(0-10 \%$ of control values) was subtracted from tumor cells adherent to platelets. Platelet-adherent tumor cells \pm SEM is given. $n$, number of experiments. Platelet preparations were human, except for the CT26 cell line experiment with antimouse von Willebrand factor, where mouse platelets were employed.

allowed us to test the hypothesis that agents inhibiting the adhesion of platelets to adhesive proteins would be successful in inhibiting metastases.

Two adhesive protein receptors have been operationally described that appear to be binding site(s) for the adhesive proteins fibronectin, von Willebrand factor, and fibrinogen (13). One contains a site that binds avidly to peptide sequences containing the tetrapeptide RGDS, and by affinity chromatography appears to be on the GPIIb/GPIIIa complex (23). RGDS is present on the alpha chain of fibrinogen, the $11,500-\mathrm{D}$ cell attachment domain of fibronectin (22), and the carboxy terminal portion of von Willebrand factor (24). The other is represented by the same and/or a different site on the platelet membrane GPIIb/-GPIIIa complex that binds a dodecapeptide/decapeptide from the - $\mathrm{COOH}$ terminal end of the gamma chain of fibrinogen $(11,25)$, and is inhibited by monoclonal antibody 10E5 (12).

RGDS inhibited binding of CT26 mouse tumor cells and HCT 8 human tumor cells to platelets by $64-69 \%$. Monoclonal antibody 10E5 inhibited binding of two different tumor cell lines to platelets by $63-66 \%$. Negative results were observed with a control monoclonal antibody, 3B2, which binds to platelet GPIIb and the GPIIb-GPIIIa complex, but has no effect on platelet aggregation (17). Inhibition of in vitro tumor cell adhesion to platelets by RGDS and 10E5 is supported by similar experiments with anti-human fibronectin antibody against both cell lines (69-82\%), antimurine von Willebrand factor antibody against CT26 (75\%), and anti-human von Willebrand factor antibody against HCT8 (81\%). Thus, von Willebrand factor as well as fibronectin promote adhesion of tumor cells to platelets. The role of fibronectin in tumor cell adhesion to subendothelial matrix is well known (26); however the role of von Willebrand factor in tumor cell adhesion has, to our knowledge, not been previously reported. Of interest was the negative effect of $6 \mathrm{D} 1$, a monoclonal antibody directed against an epitope on the von Willebrand factor binding site of GPIb. Although this epitope appears to be necessary for ristocetin-induced platelet aggregation, it does not appear to be relevant for tumor platelet adhesion. In addition, this would argue that von Willebrand factor may be interacting with its GPIIb/GPIIIa complex receptor in our in vitro system (27).

These in vitro studies are supported by in vivo metastatic studies in mice. Antimouse von Willebrand factor significantly inhibited the development of pulmonary metastases induced by three different tumor cell lines (45-64\%). In addition, 10E5 significantly inhibited the human platelet reconstitution effect on pulmonary metastasis by $77 \%$. In agreement, Humphries et al. recently reported a $67-97 \%$ inhibition of murine pulmonary metastases with the pentapeptide GRGDS, employing B16-F10 melanoma cells (28). The effect of the peptide ap- 
peared to be on the adhesion of tumor cells to the lung vasculature since there was more rapid lung clearance of tumor from the lung in the presence of the peptide. These experiments could not localize the cell type, or adhesive glycoprotein involved, however, because RGDS-containing peptides can, in addition to inhibiting platelets, inhibit the interaction between fibronectin and the fibronectin receptors present on many different cell types. Our studies support the hypothesis that RGDS inhibits metastasis formation, at least in part, by an effect on the interaction of tumor cells with adhesive proteins and platelets and/or the interaction between platelet-tumor cell aggregates with the blood vessel wall.

The mechanism of inhibition of binding of tumor cells to platelets in vitro is of interest. The various inhibitors were effective if added to platelets adherent to microtiter plates before the addition of tumor cells, with excess inhibitor washed away before the addition of tumor cells. These observations suggest that adherent platelets have exposed adhesive protein receptor binding sites. This is supported by the observation that platelet binding to plastic surfaces results in platelet activation, spreading, and release of endogenous fibronectin, von Willebrand factor, and fibrinogen bound to the platelet surface (29). Our studies do not indicate the mechanism by which the GPIIb-GPIIIa complex becomes activated in vivo. Potential candidates include ADP, thrombin or adhesion to subendothelial matrix.

The degree of inhibition of metastases by anti-von Willebrand factor antibody of $45-64 \%$ is less than the degree of inhibition with severe thrombocytopenia of $85-95 \%$ (2). This probably reflects the selective inhibition of one adhesive protein, von Willebrand factor, rather than the inhibition of fibronectin as well, and possibly other adhesive proteins and/or platelet factors. 10E5, a monoclonal antibody that inhibits binding of three different adhesive proteins to platelets was more effective in vivo, inhibiting reconstitution by $77 \%$ in all five experiments, with inhibition as high as $92-100 \%$ in two of the five experiments. It is possible that combinations of these factors may act additively or synergistically in vivo. Experiments designed to answer this question are currently in progress.

Our in vivo data do not address the question of whether platelets contribute to metastasis via platelet-tumor cell interaction with subsequent enlodgement of platelet-tumor clumps in the vasculature, via enhancement of tumor cell interaction with subendothelium or both. The extracellular matrix of the vessel wall is undoubtedly involved in metastasis. For example Liotta and co-workers (30) have reported on the role of laminin in promoting tumor cell-vessel wall interaction in metastasis. It is likely that a complex set of interactions between tumor cells, platelets, and the blood vessel wall are required for metastasis. We propose that these interactions are mediated at least in part by the binding of adhesive glycoproteins fibronectin and von Willebrand factor to the platelet GPIIb/GPIIIa receptor via their RGDS-containing regions.

\section{Acknowledgments}

We thank Ms. Anita Plotkin for expert technical assistance and Ms. Bea Grofe for the illustration.

Supported by grant 1513 from the Tobacco Research Council, grants 13336 and 19278 from the National Heart, Lung, and Blood Institutes, and a grant from Centocor, Malvern, PA.

\section{References}

1. Gasic, G. J., T. B. Gasic, and C. C. Stewart. 1968. Antimetastatic effects associated with platelet reduction. Proc. Natl. Acad. Sci. USA. 61:46-52.

2. Pearlstein, E., C. Ambrogio, and S. Karpatkin. 1984. Effect of anti-platelet antibody on the development of pulmonary metastases following injection of CT 26 colon adenocarcinoma, Lewis lung carcinoma, and B16 amelanotic melanoma tumor cells into mice. Cancer Res. 44:3884-3887.

3. Gasic, G. J., T. B. Gasic, N. Galanti, T. Johnson, and S. Murphy. 1973. Platelet-tumor cell interactions in mice. The role of platelets in the spread of malignant disease. Int. J. Cancer. 11:704-718.

4. Kolenich, J. J., E. G. Mansour, and A. Flynn. 1972. Haematological effects of aspirin (letter). Lancet. ii:714.

5. Wood, S., Jr., and P. Hilgard. 1972. Aspirin and tumor metastases (letter). Lancet. ii:1416-1417.

6. Hilgard, P., H. Heller, and C. G. Schmidt. 1976. The influence of platelet aggregation inhibitors on metastasis formation in mice. $Z$. Krebsforsch. 86:243-250.

7. Gordon, S., M. Witul, H. Cohen, J. Sciandra, P. Williams, H. Gastpar, G. P. Murphy, and J. L. Ambrus. 1979. Studies on platelet aggregation inhibitor in vivo. VIII. Effect of pentoxifyllin on spontaneous tumor metastases. J. Med. 10:435-441.

8. Honn, K. V., B. Cicone, and A. Skoff. 1981. Prostacyclin: a potent antimetastatic agent. Science (Wash. DC). 212:1270-1272.

9. Karpatkin, S., C. Ambrogio, and E. Pearlstein. 1984. Lack of effect of in vivo prostacyclin on the development of pulmonary metastases in mice following intravenous injection of CT26 colon carcinoma, Lewis lung carcinoma, or B16 amelanotic melanoma cells. Cancer Res. 44:3880-3883.

10. Kelton, J. G., J. Hirsh, C. J. Carter, and M. R. Buchanan. 1978. Thrombogenic effect of high-dose aspirin in rabbits. Relationship to inhibition of vessel wall synthesis of prostaglandin $I_{2}$-like activity. $J$. Clin. Invest. 62:892-895.

11. Plow, E. F., A. H. Srouji, D. Meyer, G. Marguerie, and M. H. Ginsberg. 1984. Evidence that three adhesive proteins interact with a common recognition site on activated platelets. J. Biol. Chem. 259:5388-5391.

12. Plow, E. F., R. P. McEver, B. S. Coller, V. L. Woods, Jr., G. A. Marguerie, and M. H. Ginsberg. 1985. Related binding mechanisms for fibrinogen, fibronectin, von Willebrand factor, and thrombospondin on thrombin-stimulated human platelets. Blood. 66:724-727.

13. Haverstick, D. M., J. F. Cowan, K. M. Yamada, and S. A. Santoro. 1985. Inhibition of platelet adhesion to fibronectin, fibrinogen, and von Willebrand factor substrates by a synthetic tetrapeptide from the cell-binding domain of fibronectin. Blood. 66:946-952.

14. Lerner, W. A., E. Pearlstein, C. Ambrogio, and S. Karpatkin. 1983. A new mechanism for tumor-induced platelet aggregation. Comparison with mechanisms shared by other tumors with possible pharmacologic strategy toward prevention of metastases. Int. J. Cancer. 31:463-469.

15. Coller, B. S., E. I. Peerschke, L. E. Scudder, and C. A. Sullivan. 1983. A murine monoclonal antibody that completely blocks the binding of fibrinogen to platelets produces a thrombasthenic-like state in normal platelets and binds to glycoproteins IIb and/or IIIa. J. Clin. Invest. 72:325-338.

16. Coller, B. S., E. I. Peerschke, L. E. Scudder, and C. A. Sullivan. 1983. Studies with a murine monoclonal antibody that abolishes ristocetin-induced binding of von Willebrand factor to platelets: Additional evidence in support of GPIb as a platelet receptor for von Willebrand factor. Blood. 61:99-110.

17. Varon, D., and S. Karpatkin. 1983. A monoclonal anti-platelet antibody with decreased reactivity for autoimmune thrombocytopenic platelets. Proc. Natl. Acad. Sci. USA 80:6992-6995.

18. Laurell, C.-B. 1965. Antigen-antibody crossed electrophoresis. Anal. Biochem. 10:358-361. 
19. Read, M. S., J. Y. Potter, and K. M. Brinkhous. 1983. Venom coagglutinin for detection of von Willebrand factor activity in animal plasmas. J. Lab. Clin. Med. 101:74-82.

20. Quatrecasas, P., M. Wilchek, and C. B. Anfinsen. 1968. Selective enzyme purification by affinity chromatography. Proc. Natl. Acad. Sci. USA. 61:636-643.

21. Ruoslahti, E., and E. Engvall. 1978. Immunochemical and collagen binding properties of fibronectin. Ann. NY Acad. Sci. 312:178-191.

22. Pierschbacher, M. D., and E. Ruoslahti. 1984. Cell attachment activity of fibronectin can be duplicated by small synthetic fragments of the molecule. Nature (Lond.). 309:30-33.

23. Pytela, R., M. D. Pierschbacher, M. H. Ginsberg, E. F. Plow, and E. Ruoslahti. 1986. Platelet membrane glycoprotein IIb/IIIa: member of a family of arg-gly-asp specific adhesion receptors. Science (Wash. DC). 231:1559-1562.

24. Sadler, J. E., B. B. Shelton-Incoes, J. M. Sorace, J. M. Harlan, K. Titani, and E. W. Davie. 1985. Cloning and characterization of two DNA's coding for human von Willebrand factor. Proc. Natl. Acad. Sci. USA. 82:6394-6398.
25. Kloczewiak, M., S. Timons, T. J. Lukas, and J. Hawiger. 1984. Platelet receptor recognition site on human fibrinogen. Synthesis and structure-function relationship of peptides corresponding to the carboxy-terminal sequence of the gamma chain. Biochemistry. 23:17641774.

26. Ruoslahti, E. 1984. Fibronectin in cell adhesion and invasion. Cancer Metastasis Rev. 3:43-51.

27. Ruggeri, Z. M., R. Bader, and L. DeMarco. 1982. Glanzmann's thrombasthenia: Deficient binding of von Willebrand factor to thrombin-stimulated platelets. Proc. Natl. Acad. Sci. USA. 79:6038-6041.

28. Humphries, M. J., K. Olden, and K. M. Yamada. 1986. A synthetic peptide from fibronectin inhibits experimental metastasis of murine melanoma cells. Science (Wash. DC). 233:467-470.

29. Lahav, J., and R. O. Hynes. 1981. Involvement of fibronectin, von Willebrand factor, and fibrinogen in platelet interaction with solid substrate. J. Supramol. Struct. Cell. Biochem. 17:299-311.

30. Terranova, V. P., L. A. Liotta, R. G. Russo, and G. R. Martin. 1982. Role of laminin in the attachment and metastasis of murine tumor cells. Cancer Res. 42:2265-2269. 